\title{
Correction \\ Correction: Cells of the synovium in rheumatoid arthritis. Chondrocytes
}

Miguel Otero and Mary B Goldring

Research Division of the Hospital for Special Surgery, Weill College of Medicine of Cornell University, Caspary Research Building, 535 E. 70 th Street, New York, NY 10021, USA

Corresponding author: Mary B Goldring, goldringm@hss.edu

Published: 16 January 2008

Arthritis Research \& Therapy 2008, 10:401 (doi:10.1186/ar2351)

This article is online at http://arthritis-research.com/content/10/1/401

(c) 2008 BioMed Central Ltd

See related review article by Goldring and Otero, http://arthritis-research.com/content/9/5/220

After publication of our recent article [1], we noticed an error in the third sentence of the third paragraph of the section entitled, 'Joint inflammation and cartilage remodeling in RA'.

This sentence should read:

ADAMTS-5 is expressed constitutively, whereas ADAMTS-4 is more prominently regulated by inflammatory cytokines.

\section{Reference}

1. Otero M, Goldring MB: Cells of the synovium in rheumatoid arthritis. Chondrocytes. Arthritis Res Ther 2007, 9:220. 